\title{
Arbetarrealism med ett stänk av magi Huset vid Flon av Kjell Johansson som en berättelse om folkhemmet
}

\section{Proletarian Realism with a Touch of Magic. Kjell Johansson's Huset vid Flon as a Narrative on folkhemmet}

Magdalena Żmuda-Trzebiatowska

\begin{abstract}
My article discusses contemporary figures of the Swedish proletarian literature on the example of Kjell Johansson's Huset vid Flon. Written in 1997 and based on autobiographical themes, the novel represents prose on childhood and growing up in the Swedish welfare state (folkhemmet). The novel's magic realistic setting can be regarded as an attempt to renew a deeply rooted genre in Swedish literature, the proletarian novel. The first part of the article addresses the relation between the form and the content of Johansson's work. The other discusses the way in which the author has used the narratives on folkhemmet that function in the Swedish academic discourse and socio-political debate.
\end{abstract}

\section{Keywords}

Swedish proletarian literature, magical realism, Kjell Johansson, the Swedish folkhem, historical narratives 
"Det må vara att allt jag berättar inte är alldeles sant, men allt har jag upplevt" - förklarar huvudkaraktären och berättaren i romanen Huset vid Flon (JOHANSSON 2003:158). Han är en medelåldersman och till yrke författare som ser tillbaka på sin barndom i det svenska folkhemmets grynigsskede, vid slutet av 1940- och i början av 1950-talet, och försöker ordna sina minnen till en sammanhängande historia. Ovanstående metatextuella kommentar, en av flera sådana i boken, visar en likhet med Kjell Johanssons vanliga svar på frågan om bokens självbiografiska karaktär. Han förnekar inte att han använt stoffet från sin egen uppväxttid men vägrar att avslöja hur mycket av det framställda som verkligen hänt och påpekar att han hellre "ligger nära känslan och ger den ett annat uttryck” än utlämnar allt (ÖHRSTRÖM, 2003).

Berättaren i romanen ${ }^{1}$ är sonen i familjen Johansson som dessutom består av fadern Johan, modern Anna och systern Eva samt inneboende morföräldrar. De hyr en förfallen kåk i utkanten av den stockholmska förorten Midsommarkransen som håller på att förvandlas till en modern arbetarstadsdel. Johanssons brottas med fattigdom, missbruk och familjevåld och de har ryktet att vara tattare, vilket påverkar barnens start i livet. Den känsliga balansgången mellan behovet att ständigt bevisa att man duger och önskan att få behålla sin integritet gör syskonen ytterst mottagliga för allt som är hemlighållett, outsagt och svårbegripligt. Den inre världen som de utvecklar i boken är lika verklig som den yttre.

Syftet med min text är att presentera Huset vid Flon som ett försök att förnya den svenska arbetarromanen genom att förse den realistiska barndomsskildringen med en magisk dimension. Analysen ska också leda till att förklara i vilken mån Johanssons bok är en berättelse om folkhemmet och på vilket sätt den är förankrad i de stora berättelserna om det svenska samhällsprojektets uppkomst, blomstringstid och fall.

\section{Arbetarlitteraturen i Sverige}

Till 1930-talet dateras en företeelse som i den svenska litteraturhistorien brukar kallas "parnassens demokratisering". ${ }^{2}$ Författare med rötter i landsbygdsproletariatet och autodidakters erfarenheter som Ivar Lo-Johansson, Harry Martinson, Jan Fridegård eller Moa Martinsson har med sina realistiska skildringar utmanat den vedertagna föreställningen om skönlitterärt skapande som en del av finkulturen och vunnit uppskattning i läsar- och kritikerkretsar. Idag betraktas deras verk som ett litterärt arv som nya generationer av författare och läsare öser ur. Elsie Johansson, Åsa Linderberg, Susanna Alakoski eller Kjell Johansson är bara några exempel på författare som betraktas som representanter för den nya vågen i den svenska arbetarlitteraturen.

Begreppena arbetarlitteratur och arbetarförfattare har sina ursprung i de nära besläktade och i flera sammanhang utbytbara termerna proletärlitteratur och proletärför-

1 I Huset vid Flon är han namnlös; namnet Einar dyker upp först i den fristående fortsättnigen Sjön utan namn (2001).

2 Benämningen har använts av Lennart Thorsell i hans uppsats "Den svenska parnassens «demokratisering» och de folkliga bildningsvägarna”, ursprungligen tryckt i Samlaren år 1957. 
fattare $^{3}$ som var i bruk sedan 1920-talets början och syftade på tiotalister som saknade förankring i borgerligheten. Benämningen proletärförfattare introducerades av Rickard Steffen i hans antologi för skolbruk från år 1921 och den väckte en häftig diskussion som först och främst pågick i Socialdemokraten. De som berördes reagerade olika. Medan Martin Koch och Gustav Hedenvind-Eriksson betraktade klassificeringen som uppskattning, hederstitel och inbjudan till den litterära eliten ansåg Ivan Oljelund, Harry Blomberg och Ragnar Jändel att termen var en stigmatiserande etikett som stängde in alla i ett fack. En lika splittrad inställning visade kritiker. De socialdemokratiska skribenterna använde termen i positiv bemärkelse, för de borgerliga blev den synonym med nedsättande beskrivning av litteratur som fylls med ideologisk innebörd på bekostnad av dess estetiska värde (AHLMO-NILSSON 1979:8f).

Kring 1970-talets mitt betraktades begreppen arbetarlitteratur och arbetarförfattare som starkt ideologiskt laddade och väckte därför stora kontroverser. Bland dem som tog ett tydligt avstånd från termerna var Georg Brandell som valde att inte använda dem i sitt verk Svensk litteratur 1870-1979. Han ansåg "arbetarförfattare" som en omotiverad benämning på en särskild grupp författare i svensk 1900-talslitteratur och ifrågasatte motsättningen mellan tiotalets borgerliga och proletära realister. Istället för den socialt bestämda karakteristiken av författarna föreslog han en litterär: 1930-talets representanter för statarskolan kallade han för proletärskildrare, vilket kan tyda på att han betraktade arbetarlitteraturen som underavdelning av folklivsskildring. "För Brandell går det inte någon avgörande skiljelinje mellan skildringar som tecknar arbetarna utifrån, utan lojalitet, utan att känna deras förhållanden och skildringar där arbetarnas problem skildras lojalt, såsom arbetarna själva upplever dem”, konstaterar Birgitta AHLMONILSSON (1979:10).

Kontroverser kring begreppet arbetarlitteratur har resulterat i att termen som idag framstår som tämligen okomplicerad i vardagsspråket fortfarande bereder stora definitionsmässiga svårigheter (NILSSON 2006b:154). I talrika försök att kartlägga vad arbetarlitteratur är har forskarna följt tre kriterier, nämligen författare, läsare och innehåll. Enligt den ofta citerade definitionen i boken Svensk arbetarlitteratur av Lars FURULAND och Johan SVEDJEDAL (2006:23) handlar arbetarlitteratur om arbetare, är skriven av författare med ursprung i arbetarklassen och dess tilltänkta mottagare är arbetare, men det är inte nödvändigt att alla tre kriterier är uppfyllda. Att definitionen är så bred är enligt Magnus NILSSON (2006b:156) både dess svaghet och styrka. Den förefaller ganska vag och kan tillämpas på en rad litterära verk av skilda slag, men samtidigt möjliggör den att ta upp olika aspekter av fenomenet arbetarlitteratur. Eftersom Nilssons resonemang innehåller en rad viktiga iakttagelser tycks det motiverat att sammanfatta det i all korthet.

Den mest problematiska komponenten i definitionen tycks vara författare. Arbetsklassbakgrund kan både syfta på familjeförhållanden (en person vars föräldrar är arbetare), arbetserfarenheter (en person som har erfarenheter av kroppsarbete, lönearbete, industriarbete) eller den ekonomiska situationen (en person som lever under knappa förhållanden). Att bara bestämma sig för en tolkning skulle leda till att exkludera flera

3 Genom användning av adjektivet "proletär" riktas ett särskilt fokus på det ideologiska perspektivet i böckerna (FURULAND 1999:527). 
kända författare som t. ex. en av arbetarlitteraturens pionjärer Martin Koch, som kom från en småborgerlig familj, eller representanter för statarskolan, som Ivar Lo-Johansson och Jan Fridegård som inte härstammade från den egentliga arbetarklassen (NILSSON 2006b:157ff). I detta sammanhang får man också ge exempel på definitioner som var träffande med avseende på en viss företeelse och framstår som inte längre aktuella. Tyngdpunkten i Steffens tidiga definition låg på att proletärdiktare var autodidakter och detta begrepp användes ofta synonymt med arbetarförfattare om trettiotalister, men verkar knappast användbart idag. (NILSSON 2006b:159). Lars Furuland, som i boken Statarna i litteraturen 1962 betonade att arbetardiktare är knutna till arbetarrörelsen, fick också revidera sin definition som bäst passande på representanter för den första vågen av arbetarlitteraturen då författarna publicerades på arbetarrörelsens förlag och deras verk distribuerades inom organisationen (NILSSON 2006b:155).

Arbetarlitteratur brukar ofta beskrivas som litteratur som vänder sig till arbetare, litteratur som tar ställning för arbetarklassen eller skildrar världen ur arbetarperspektiv. Innehållet i böckerna och författarnas engagemang i arbetarrörelsen anses då viktigare än skaparnas klassbakgrund. Definitioner där mottagaren sätts i fokus betonar oppositionen mellan arbetarlitteratur och borgerlig litteratur. Det är också vanligt att peka på proletärt klassmedvetande som genomsyrar böckerna - därmed förstår man "ett medvetande om att arbetarklassens intressen står i antagonistisk motsättning till borgerlighetens" (NILSSON 2006b:160). Att flera arbetardiktare, t.ex. trettiotalister, började läsas av arbetarklassen först efter att de hade slagit igenom och efter att ha blivit klassificerade som arbetarförfattare är dock en omständighet som underminerar definitioner av denna typ. Som en förenkling kan dessutom betraktas försök att ställa likhetstecken mellan arbetarnas och arbetarrörelsens perspektiv, eftersom det finns bland arbetare och författare med arbetarbakgrund sådana som tagit avstånd från arbetarrörelsen (t.ex. R. Jändel, I. Oljelund och H. Blomberg). Nilsson lägger också märke till att socialistisk tendens i böckerna och skaparens engagemang för arbetarklassen kan men inte behöver vara avgörande vid klassificeringen av någon som arbetarförfattare om förankringen i arbetarklassen uteblir, t.ex. brukar Ture Nerman sällan räknas till arbetarförfattare (NILSSON 2006b:162f). ${ }^{4}$

Att endast tillämpa det tredje kriteriet, nämligen definiera arbetarlitteratur som litteratur om arbetarklassen är däremot ganska ovanligt vid försök att definiera arbetarlitteratur. Motiv och miljö framhålls som viktiga i kombination med andra kriterier, främst det ideologiska perspektivet. Arbetarklassbakgrund är också viktigt i detta avseende och framstår som garanti att det som berättas är självupplevt och äkta. Förutom den tidigare signaliserade frågan om in- respektive exkludering av författare utan arbetarbakgrund som Koch eller Nerman kan man här också undra vilken klassificering är lämplig för verk som inte skildrar arbetarklassen, men är skrivna av författare med arbetarbakgrund. (NILSSON 2006:164).

Magnus NILSSON förklarar att det finns så många och skilda definitioner av begreppet arbetarlitteratur eftersom de användes på olika sätt och vid olika tidpunkter. Det

$4 \AA ̊$ Andra sidan öppnar mottagar-och innehålsinriktade definitioner för att klassificera Viktor Rydberg, Gustaf Fröding eller Verner von Heidenstam som arbetarförfattare eftersom de i några verk har förmedlat arbetarperspektivet, eller i alla fall åsikter som delades av arbetarrörelsen (NILSSON 2006b:160ff). 
är både språkbruket som förändras och arbetarlitteraturen. Den definition som han anser vara universell och täcka alla existerande definitioner utgår därför från litteraturreceptionen, nämligen att arbetarlitteratur är "litteratur som av läsaren kopplas samman med arbetarklassen" och denna sammankoppling "framstår som dominerande faktor" vid läsningen (2006b:166). Men eftersom alla definitioner är historiska kan anledningar till den ovannämnda sammankopplingen variera i likhet med kriterier som använts av litteraturvetare.

\section{Magisk realism}

Sedan begreppet magisk realism på 1960-talet gjorde sig hemmastatt i litteraturen har det spridits snabbt inom såväl litteraturkritiken som litteraturvetenskapen. Så småningom har det lyfts ur sitt ursprungliga, latinamerikanska sammanhang för att beskriva en rad besläktade fenomen som observerats i nationella litteraturer i världens alla delar. Termen har i första hand tillämpats på den postkoloniala litteraturen i den breda bemärkelsen och dess sätt att skildra erfarenheter av marginalisering av människor och platser men idag är dess användning bredare. Skildringar av minoriteter och andra utsatta grupper kan klassificeras som magisk realism oavsett kulturkretsen som de kommer från och den samhälleliga kontexten som de är förankrade i, särskilt om de utmanar de rådande nationella berättelserna. Parallellt med denna utveckling har också populärlitteraturen och -kulturen gjort anspråk på inriktningen vilket har resulterat i en uppsjö böcker och filmer befolkade med vampyrer, varulvar och andra mytiska varelser, där gränsen mellan magisk realism och fantasy (med subgenrer urban fantasy eller dark fantasy) förefaller ganska suddig.

På svenskt håll saknas det hittills några mer omfattande studier som handlar om den magiska realismens representation i den inhemska litteraturen, men det finns ett antal artiklar och uppsatser som vittnar om att perspektivet har vunnit insteg i forskningen. ${ }^{5}$ Som föregångare för magisk realism i svensk tappning brukar vanligen Selma Lagerlöf utpekas och bland samtida verk som anses tillhöra inriktningen nämns ofta Aprilhäxan av Majgull Axelsson och några romaner av Marianne Fredriksson, i synnerhet Simon och ekarna. Andra exempel på romaner med utgångspunkt i verkligheten och inslag av magi är Juloratoriet av Göran Tunström, Populärmusik från Vittula av Mikael Niemi eller Havsmannen av Carl Johan Vallgren.

För att diskutera den formförnyelse av arbetarromanen som Kjell Johansson åstadkommit genom att förse sin realistiska skildring med en övernaturlig dimension ska jag anknyta till den numera klassiska definitionen som har formulerats av Wendy B. FARIS i hennes essä "Scheherazade's Children: Magical Realism and Postmodern Fiction." Hon

5 Som ett intressant bidrag till forskningen kan nämnas uppsatsen Övernaturliga vardagar. En studie av det övernaturliga i svensk litteratur som medel för social kritik (2007) där Paola MASDEU undersöker närvaro av magi och övernaturliga element i romanerna Aprilhäxan av Majgull Axelsson, Lät den rätte komma in (2004) och Hantering av odöda (2005) av John Ajvide Lindqvist samt i novellsamlingen Till vår ära av Alejandro Leiva Wenger (2001). 
urskiljer fem konstitutionella egenskaper hos den magiska realismen. Den första beskriver hon som "an «irreducible element» of magic", och syftar därmed på företeelser som inte kan förklaras med hjälp av fysikens lagar (1995:167). Det magiska händer i texterna "på riktigt", det framställs inte som illusion eller hallucination, men samtidigt som de magiska inslagen är väl integrerade i texten kan de betraktas som något som dekonstruerar berättelsen, bryter ned den, t.ex. genom att rubba den kausala logiken.

Den andra egenskapen avser "the realism in magical realism" (FARRIS 1995:169), dvs. sättet att återge det realistiska skeendet. Detaljrikedomen i beskrivningen gör att den värld som gestaltas blir möjlig att känna igen för läsaren, detsamma gäller karaktärer. Men i motsats till verk som är representativa för realism är magisk realism ingen mimetisk konst och handlar inte om att reproducera verkligheten utan skapar en ny tolkning av den, vilket blir möjligt genom magiska inslag.

Läsaren av magiskrealistisk litteratur pendlar mellan två motsatta perceptioner av de beskrivna händelserna och som följd därav tvivlar på vad som är verkligt. Graden av detta tvivel varierar beroende på läsarens kulturella bakgrund och behovet att förklara det oförklarliga resulterar i att magiska inslag tolkas som karaktärernas drömmar eller hallucinationer. Enligt FARRIS (1995:171) är tvivelmomentet det tredje draget som karakteriserar en magiskrealistisk text.

"The magical realist vision exists at the intersection of two worlds, at an imaginary point inside a double-sided mirror that reflects in both directions", förklarar FARRIS (1995:172). Hennes fjärde kriterium syftar på den relation som uppstår när den verkliga och den övernaturliga världen möts i berättelsen. De existerar parallellt men ständigt griper de in i varandra, eftersom gränserna mellan dem är flytande.

Den femte och sista obligatoriska egenskapen för en magiskrealistisk berättelse är att de vedertagna kategorier av tid, rum och identitet blir ifrågasatta i den. Tiden är inte längre linjär, rummet kan vara flerdimensionellt och identiteten splittras i pusselbitar (FARRIS 1995:174).

De sekundära och fakultativa specifikationer som FARRIS räknar upp och som alla hör hemma i den postmodernistiska poetiken är textens metafiktiva karaktär, användning av lingvistisk magi ("verbal magic"), skenbart barninriktat berättande, upprepningar som ett berättartekniskt grep och speglar som en frekvent förekommande symbol samt metamorfoser, vars roll är att illustrera sammanstötningen mellan två världar. Vidare nämner hon den antibyråkratiska, närmast revolutionära andan som ofta genomsyrar magiskrealistiska verk där magi bidrar till att undergräva den rådande samhällsordningen och befria den förtryckta gruppen. Det är dessutom vanligt att magisk realism öser ur gamla trossystem och lokala vidskepelser (1995:175-183). FARRIS instämmer också i vad litteraturkritikern Seymour Menton har konstaterat om att "a Jungian rather than a Freudian perspective is common in magical realist texts" (1995:183). Därmed lyfter hon fram den kollektiva dimensionen av magi på bekostnad av de mer individuella realisationer. 


\section{Berättelsen om utsatthet}

Kjell Johansson föddes år 1941 i Stockholm i en arbetarfamilj och växte upp i Midsommarkransen. Som sin framtid såg han först idrotten, han tränade fotboll och boxning. En annan ungdomsidé var att bli gruvarbetare på Spetsbergen, men till sist valde han att satsa på utbildning. Efter högskolestudier arbetade han som lärare på komvux tills han bestämde sig för att bli yrkesförfattare. År 1989 slog han igenom med romanen Gogols ansikte där han gav uttryck för sin fascination över rysk litteratur. Boken blev uppskattad av läsare och kritiker och nominerades till Augustpriset.

Bland de faktorer som har bidragit till att Johansson klassificeras som arbetarförfattare, vilket han själv anser vara "oerhört hedrande" (FURULAND 2006:373), kan man i första hand nämna hans ursprung och de yrkeslivserfarenheter som han samlat (som vaktmästare, hemsamarit, hamnarbetare). Viktigt att påpeka är också att Johansson var en av fyra författare som vid mitten av 1980-talet grundade arbetsgruppen Fyrskrift, vars uppgift skulle vara att ta debatten om begreppen realism och arbetarkultur samt återupprätta arbetarlitteraturens prestigefyllda ställning på den svenska bokmarknaden. I gruppen ingick dessutom Hans Lagerberg, Gunder Andersson och Reidar Jönsson. I förordet till novellsamlingen Vägarbete från år 1985 förklarade de att arbetarlitteraturen inte borde associeras med något tråkig även om den handlar om vanliga människor som bor i förort, har en anställning och åker buss eller bil till jobbet (NILSSON 2006a:88).

Johansson uppfyller också det ideologiska kriteriet, som omnämns i Nilssons resonemang. Författarens två första böcker Det finns en krog på väg till varje revolution (1972) och Lenins dröm (1974) genomsyras av vänsterradikalt perspektiv. Han uttrycker kritik mot socialdemokraternas reformistiska linje och i sin närmast revolutionära retorik närmar han sig politisk agitation. Peter Luthersson påpekar att med den självbiografiska Huset vid Flon ger författaren, som själv har upplevt orättvisa och förnedring, „en högst begriplig bakgrund till sin revolutionsromantik” (LUTHERSSON 1999:627). Enligt Lars FURULAND som i Svensk arbetarlitteratur skriver om ett paradigmskifte som skedde under 1990-talet då kulturredaktionerna tröttnade på postmodernismen och istället började satsa på litteratur "med tydlig anknytning till den gamla klassiska arbetarskildringen" är Kjell Johansson en av dem som gynnats av det nya kulturklimatet (2006: 336f).

Huset vid Flon (1997) åtföljdes av de två fristående uppföljarna Sjön utan namn (2003) och Rummet under golvet (2006). För sin romantrilogi där en släkts historia återberättas ur olika synvinklar har författaren valt titeln De utsatta. Den sociala utsattheten är ett av motiven som frekvent förekommit i den svenska arbetarlitteraturen men i Huset vid Flon är den knappast ett resultat av klassmotsättningar som i boken signaliseras bara vid enstaka tillfällen ${ }^{6}$ utan framstår som arbetarklassens inbördes problem.

I sin essä som handlar om Kjell Johanssons författarskap påpekar Agneta PLEIJEL (2011) att författaren inte ansluter sig till den definition av arbetarklassen som arbetarrörelsen står för. Definitionen i fråga sammanfaller i mycket med termen ”den skötsamme arbetaren" myntad av idéhistorikern Ronny Ambjörnsson och syftar på de tämligen

6 Till exempel när husets ägare, herr Wellin kommer för att inkassera hyran (JOHANSSON 2003: 79-80). 
oproblematiska, partilojala och lättstyrda gräsrötterna i den socialdemokratiska välfärdsstaten, människor som utrustats med hög arbetsmoral, övertygelse att man ska göra rätt för sig och osviklig framtidstro, duktiga kuggar i det stora maskineriet som genom sina arbetsinsatser bidrar till allas bästa. I centrum för Kjell Johanssons intresse står däremot - med Pleijels ord - "den oskötsamme arbetaren" och han skriver om personer som har hamnat i folkhemmets utkanter och definierats som missanpassade, asociala och ovälkomna i gemenskapen.

Man får instämma i denna iakttagelse. Johanssons karaktärer passar inte riktigt i den mall som den socialdemokratiska välfärdsstaten har ritat för sina medborgare. Att skildringar av arbete, arbetsglädje och arbetsstolthet är ytterst sällsynta i boken ${ }^{7}$ är ett annat tecken på att författaren undviker stereotypa bilder som ibland kan associeras med efterkrigstidens arbetarlitteratur. Anna, modern i familjen Johansson, försöker visserligen lappa familjebudgeten med städjobb men säger upp sig när hennes make återvänder hem och lovar att hitta fastanställning. Johan Johansson har dock ingen vana av tungt arbete och dessutom känner han förakt mot de vanliga representanter för arbetarklassen som sliter från morgon till kväll. Att han till slut börjar arbeta beror på att hans son av barnavårdsnämnden har placerats i fosterhem och får komma tillbaka först när föräldrarna har bevisat att de duger. Helst satsar Johan på olika, ofta orealistiska affärsidéer som att fotografera kvarterets ungar och sälja fotografier till föräldrarna eller uppträda som gårdsmusikant. Denna lättsinniga inställning till livet är till ständig förtret för morföräldrarna som anser att deras dotter genom äktenskapet har förlorat sin chans till ett bättre liv. Johanssons levnadssätt väcker också ont blod hos de vanliga, skötsamma arbetarna som gärna klistrar på sina grannar etiketter som tattare eller socialfall. Anmärkningsvärt är att det minst av allt handlar om familjens ekonomiska situation: Johanssons är fattiga men de lever inte på existensminimum, de kan unna sig en festmåltid på söndag och ett konditoribesök då och då. Barnens kläder är inte trasiga och trots att bostaden saknar badrum och toalett är Anna angelägen om att hålla rent hemma. "[D]e flesta i Kransen hade det som vi”, förklarar berättaren (JOHANSSON 2003:108).

Huset där Johanssons bor är dock en viktig markör för familjens sociala status. Tattarkåkar finns enligt författaren i varje stad eller by och används som välfungerande medel för att segregera de "av sämre sort" från de "präktiga och hedervärda":

"I en sån där kåk placerar fattigvården eller socialen eller tillfälligheten folk som inte beter sig som andra, som super, till exempel. Och super de inte mer än andra så horar de, och horar de inte så lever de fan på något annat sätt. Och om de inte lever fan och om de har arbete och sköter sig och verkar vänliga och renhåriga på alla sätt så är det bara ett osedvanligt lömsk trick för att lura de vanliga, ty hur man än vänder och vrider på saken så är de annorlunda än vanligt folk, mörkare på något sätt, både på utsidan och på insidan, smutsigare, snuskigare och fattigare" (JOHANSSON 2003:13).

7 Ett undantag är beskrivning av asfaltering av gatorna i Midsommarkransen, som jag återkommer till i den sista delen av min text. 
Analysen av utfrysningens psykologiska mekanismer ger vid handen att existensen av människor som kan klassificeras som samhällets avskum är ett slags garant för de vanligas välmående: "Utan oss vore de vanliga ingenting" (JOHANSSON 2003:13).

Mellan de skötsamma och de oskötsamma går en tydlig skiljelinje. Grannarna förbjuder sina barn att leka med Eva och hennes bror, syskonen släpps inte på ett födelsedagskalas och Johanssons har nästan inget umgänge alls. Den sociala utfrysningen har en fysisk dimension men lämnar djupa emotionella spår.

Samtidigt som Kjell Johansson tar avstånd från en alltför idealiserad bild av arbetarklassen är han utan tvekan inspirerad av den svenska arbetarlitteraturens rika tradition. Detta kan iakttas på flera ställen i boken. Hans romankaraktärer, mormodern Lotten och modern Anna, är t.ex. en del av den svenska folkbildningskulturen. Den första har arbetat på ett litet studiecirkelbibliotek och hennes bildningstörst och förkärlek för böcker har smittat av sig på dottern. Förutom att läsa diskuterar de också litteratur och är oense om vilken av arbetarförfattarna som är störst, Harry eller Moa Martinsson (JOHANSSON 2003:21;54). Anna köper ibland begagnade böcker trots att hon egentligen inte har råd och uppmuntrar sina barn att läsa genom att bl.a. gå med dem på bibliotek (JOHANSSON 2003:55). Att läsa är för henne en närmast religiös upplevelse - hon brukar sätta sig i sin favoritfåtölj och använda ett bokmärke med monogram (JOHANSSON 2003:21f). Hon blir överlycklig när maken köper henne Åhlen \& Söners uppslagsbok i tretton band i julklapp. "Det var inte skam att inte kunna men det var en skam att inte vilja lära sig", uppmanar hon sina barn (JOHANSSON 2003:116).

Johanssons, framför allt Anna, tror på kunskapen som ett sätt att förverkliga sig själv: "Att vara någon som kunde och visste mycket var något stort, det var att ha kommit en god bit på vägen till att bli en bättre människa" (JOHANSSON 2003:117). Hon döljer inte heller att hon betraktar utbildningen som de fattigas enda väg till en bättre framtid, "ett stege som kunde resas upp till ett annat liv." När Eva får en rekommendation att söka till läroverket är föräldrarna stolta över hennes läsbegåvning. De är också beredda att lägga ut de medel som behövs för hennes fortsatta studier. Samtidigt fantiserar de om att Eva - liksom Askungen - en dag träffar sin prins - en elegant, väluppfostrad och bilburen medlem av högre klass (JOHANSSON 2003: 207f).

Klassresan, ett annat känt motiv från arbetarlitteraturen, förekommer också i Huset vid Flon. Det var morföräldrarna som genom att flytta från landsbygden till staden tog det första steget mot socialt avancemang. När det gäller föräldrarna har de knappast någon möjlighet att förbättra sin position i samhället. Visionen om ett bättre liv hägrar då och då när Johanssons planerar att köpa ett kylskåp eller bestämmer sig för att prenumerera på en tidning, men den skingras när fadern misslyckas med sina affärer och återfaller i missbruk. Att Johan Johansson gärna lägger sig till med herrskapsfasoner och spelar greven av Midsommarkransen vittnar om hans ambition att framstå som något bättre än en försupen trasproletär. Han vill dock inte mödosamt klättra upp steg för steg utan drömmer om att skaffa sig en förmögenhet och förflyttas direkt till toppen. Samtidigt får man också påpeka att Anna genom äktenskap med Johan har glidit ner i samhällshierarkin och fått finna sig i att vara en allmänt föraktad tattarhustru. Medan hans make ser ner på de skötsamma, satsar för högt och är dömd att misslyckas, önskar hon mest 
att bli en av de vanliga. Detta mål uppnår hon efter Johans död. Jobbet i en butik med sybehör och sedan i kassan på ett snabbköp och egen lägenhet med badrum, toalett och många böcker är hennes sätt att smälta in och vara som alla andra. Hon blev "[e]n vanlig arbetarkärring, som hon inte utan stolthet kallade sig”, kommenterar sonen (JOHANSSON 2003: 340). Den riktiga klassresan gäller dock framför allt för barnens generation. Syskonen Johansson har båda fått högskoleutbildning och lämnat sitt ursprungsmiljö men de har inte blivit av med sina rötter, vilket är särskilt tydligt i Evas fall. ${ }^{8}$ En del av deras skolkamrater har också gjort klassresan, bl.a. Roffe Jansson, berättarens plågoande och sedan buskompis som har blivit bibliotekarie. (JOHANSSON 2003: 313f)

Ideologin får inte någon exponerad plats i romanen, bortsett från den vuxne berättarens kommentarer om folkhemmet, som jag återkommer till senare. Johanssons är inte aktiva politiskt och inte heller medlemmar i någon folkrörelse och deras intresse för det aktuella skeendet tycks medelmåttigt. Som en socialistisk agitator i Hjalmar Brantings anda framstår däremot mormodern Lotten som försöker få barnbarnen intresserade av de läror som hon insupit som ung. När hon övar läsning med Eva och hennes bror använder hon en bok om Branting. Hon brukar förhöra syskonen på innehållet och ser till att de förstår vad de lärt sig genom att kommentera och förklara. Mormorn berömmer t.ex. Eva för det rätta svaret på frågan "Vilka är socialisterna?" men anser att listan måste kompletteras: "Fast det finns faktiskt också liberaler och högerpartister som är socialister. Men det vet de inte om. Goda människor är socialister, så det ska ni bli, barn, sa mormor och det var inte en förhoppning utan en befallning” (JOHANSSON 2003: 18). Först i vuxen ålder inser berättaren att hennes historier om "grymma borgherrar och de förtryckas uppror" var en fri bearbetning av "socialismens klassiska skrifter" (JOHANSSONS 2003: 27). Då begriper han också att mormorns fördömande av trasproletärer som fiender i arbetarklassens egna led var i första hand riktat mot Johan Johansson, den opålitlige maken till hennes dotter och fader till hennes barnbarn.

\section{Den magiska berättelsen}

I Svensk arbetarlitteratur fastställer Lars FURULAND att Kjell Johansson i Huset vid Flon "vidgade ramarna för realismen" (2006:373). Forskaren använder dock inte termen magisk realism utan kallar berättelser i boken för skrönor, vilket kan vittna om en viss misstro mot en stilart som kan förefalla främmande för arbetarlitteraturen. I det följande vill jag med hjälp av exempel ur boken bevisa att alla obligatoriska och några fakultativa egenskaper som Farris anser vara karakteristika för magisk realism kan identifieras i Johanssons roman.

De övernaturliga inslag som förekommer i Huset vid Flon kan delas in i några kategorier. Det är väsen med rötter i folktron, föremål med starkt symbolisk laddning, obegripliga händelser och företeelser, personer som lever på gränsen mellan två världar och

8 Hon brottas med psykiska problem, vistas på mentalsjukhus och gör självmordsförsök.

9 "Socialisterna är socialdemokrater och kommunister och syndykalister och ävenledes stundom kommunister", svarar Eva (JOHANSSON 2003:18). 
berättelser som har magisk kraft. De är inflätade i berättelsen och tillsammans bildar de ett kitt som får historien om barndomen i folkhemmet att hålla samman. I detta avseende är de, med Farris språkbruk, "oreducerbara".

Naturområdet Flon som låg intill den kåk som Johanssons bodde i skildras av den vuxne berättaren som en hemvist för olika slags väsen som väckte rädsla men också nyfikenhet hos barnen:

\begin{abstract}
"Mest fruktade jag myrdingarna som levde under marken i Floängen och i den bottenlösa Myrdingen, som var en liten sjö eller snarare en stor damm. På nätterna hördes deras sånger, de sjöng om fruktansvärda illgärningar och i mörkret smög de in på gårdsplanen, mörka skuggor omkring huset. Ännu på morgonen kunde man ana dem som väsningar från buskarna och förstå deras önskan, att ta sig in och berätta” (JOHANSSON 2003: 11).
\end{abstract}

Myrdingar eller mylingar är i folktron vålnader av mördade odöpta barn som gråter, skriker eller sjunger sorgsna sånger om sitt öde. Oftast vistas de i närheten av platsen där deras kroppar blivit gömda. Enligt sägnerna kan de vara hämndlystna och farliga men ibland söker de upp människor för att be om dop eller begravning. Myrdingar återkommer på flera ställen i boken, bevis på deras "existens" ser barnen överallt. Det kan t.ex. vara små hål i marken "kanske efter tältstöttorna eller efter sorkarna eller möjligen myrdingarna, svag sång kan höras därnerifrån" (JOHANSSON 2003: 51). Både pojken och hans syster har hört myrdingar sjunga och Eva påstår att hon har sett dem: "De har ett stort huvud men inget ansikte. De liknar huvudfotingar vi ritade när vi var mindre" (JOHANSSON 2003: 53).

Vildhunden är en annan mystisk varelse vars närvaro barnen kan förnimma med hörsel och lukt. Kopplingen till folktron där den stora svarta hunden ofta står för djävulen, döden och magin verkar finnas också i detta fall. ${ }^{10} \mathrm{I}$ Huset vid Flon representerar vildhunden det obegripliga, det som samtidigt inte finns och finns, det som samtidigt är lockande och skrämmande:

”Vi har tankar om vildhunden som ingen sett och som i så måtto påminner om vinden. Många påstår att vildhunden inte finns, men aningen om hans flykt kan förmärkas en sådan här dag även om den tydligast känns en tidig morgon - då viltlukten dröjer kvar i det höga gräset och kan spåras ända uppe i kallstråket - eller på natten då man vaknar av hans vilda skrik, det som genast dör ut i den askgrå tystnaden" (JOHANSSON 2003: 51).

De talrika oförklarliga eller mystiska händelser som barnen är med om är välintegrerade i de realistiska skildringarna av Johanssons vardag där familjemys och familjevåld avlöser varandra. Syskonen springer efter vinden, försöker mäta "kallstråket" som går över gården och lyssnar på den magiska tjukans berättelser om livet i de värmländska skogarna, faderns hemtrakter. De skyr också den svarta dodgen som sägs köra längst gatorna med

10 När Johan Johansson påstår att den avlidna mormodern går igen som svart katt undrar sonen om det inte var vildhunden som far har sett: "En vildhund, särskilt om den inte finns, förvandlar sig lätt till en katt om den tycker sig ha en anledning" (JOHANSSON 2003: 321). 
barnnämndens representanter ombord och plocka upp bråkiga ungar för att sedan placera dem på fosterhem (JOHANSSON 2003: 95). Vid några tillfällen upplever barnen också konstiga möten med okända personer som dyker upp i deras närhet för att sedan spårlöst försvinna (JOHANSSON 2003: 52; 281).

Eva och hennes bror blir också vittnen till situationen då deras grannar är med om något ovanligt. Pojken ser på när Lilly Klarin som kallas för "Hon den tjocka” åker sula nedför en snöig och hal gata. Istället för att ramla eller i rasande fart passera förbi den portuppgång som varit hennes mål gör hon några avancerade skridskofigurer och lyckas bromsa i rätt tid (JOHANSSON 2003: 108).

Den av romanens karaktärer som framförallt tycks vara besatt av mörka hemligheter är Eva. Hon framstår som ett slags medium som förmedlar kontakter mellan det jordnära och det ovanliga, mellan den folkhemska verkligheten och den hemliga, okända, fascinerande sfären som bara några har tillgång till. Flickan säger sig ha makt över de varelser som dyker upp i historier som hon berättar för sin bror. Att Eva fick en vit fläck i stället för ansikte på den bild som Johan Johansson tog då han fotograferade ungar i Midsommarkransen kan betraktas som ytterligare ett tecken på hennes mellanställning (JOHANSSON 2003: 72). Samtidigt utgör informationen om hennes psykiska ohälsa i vuxen ålder, som läsaren får då berättaren byter från berättelsens till berättandets tid, det tvivelmoment som Farris skriver om i sin karakteristik av magisk realism: man börjar undra vad som hänt på riktigt och vad som fantiserats ihop i den barndomsskildring som Kjell Johansson skapat.

Fadern i Huset vid Flon, Johan Johansson, är en annan gestalt som spränger gränserna för den objektivt existerande världen och liknar sin dotter när det gäller förmågan att se och känna mer än andra. Han letar också efter sin plats i skärningspunkten mellan drömmen och verkligheten och misslyckas. ${ }^{11}$ Samtidigt är han den introverta, högkänsliga Evas motsats - utåtriktad, högljudd, auktoritär. I det dagliga livet framträder han som försupen, våldsam och arbetsskygg, men sonen uppfattar honom som intelligent, begåvad och uppfinningsrik. När fadern var borta (till sjöss eller i fängelset) har barnen, i synnerhet pojken, skapad en idealiserad bild av honom. Tron på den magiska berättelsen som fadern bär på är ett återkommande motiv i boken (JOHANSSON 2003: 27). Dess symbol blir hästklockan - tjukan som hänger i farstun och berättar för barnen om det som väcker smärtsamma minnen hos Johan Johansson: tattarsläktet i den värmländska finnbygden, ungdomsåren på ett skogstorp i Värmland, favorithästen Aron och den konfliktfyllda relationen med hans egen far (JOHANSSON 2003: 29f; 49ff; 167ff; 311f).

Skrönaktiga historier om grannar och händelser ur deras liv framstår som lättare att berätta. Fadern förklarar t.ex. att "Miljonären", Samuel Rask, som blev rik på att uppträda på gårdar, någon gång ägde en förtrollad flöjt som garanterade honom framgång. Att Rask som förr var hans nära vän numera vänder bort blicken när han passerar Johanssons på gatan beror på att han skäms över att ha gjort sig av med alla vänner (JOHANSSON 2003: 59). En annan historia handlar om den mirakulösa metamorfosen av Lilly Klarin. Från en överviktig ensamstående mor med öknamnet "Hon den tjocka"

11 Johan Johansson faller allt mer i missbruk, vilket leder till hans förtidiga död under oklara omständigheter. 
har hon förvandlats till en utomordentligt vacker och attraktiv kvinna som liknar en filmstjärna, drar till sig allas blickar, väcker beundran hos männen och avundsjuka hos deras hustrur. Hon får genast smeknamnet Marilyn och en mängd friare. Motvilligt accepteras hon även av dem som förr såg ner på henne som ogift och alltför frigjord. (JOHANSSON 2003: 209ff). Eftersom ingen märkte när förvandlingen exakt ägde rum gissar Johan Johansson att "Hon den tjocka i alla år var havande med framtiden, alltså med Marilyn”. Han skapar också några teorier om vad som hänt med den gamla Lily Klarin och kommer fram till slutsatsen att hon måste ha dött vid nedkomsten, för "döden är en nödvändig förutsättning för livet” (JOHANSSON 2003: 212).

Historier från barndomen utgör bokens stoff men när de återberättas av den vuxne författaren används de samtidigt som verktyg för att konstruera romanen, de får ett nytt liv och en ny funktion. På ett postmodernistiskt men också magiskrealistiskt manér leker författaren med sina berättelser, ifrågasätter eller bejakar dem. Han antyder t.ex. på flera ställen att olika slut är möjliga, att han inte minns tydligt eller skissar en alternativ, önskvärd avslutning. Kronologisk skildring bryts vid upprepade tillfällen, vissa händelser är svårplacerade i tiden eller har blivit omplacerade - medvetet eller till följd av författarens minnesbrister, vilket erkänns och förklaras i metatextuella kommentarer.

De magiska inslagen i berättelsen kan tolkas som ett försök att fly den grymma verkligheten eller åtminstone göra den mer uthärdlig. Myrdingar, vildhunden och andra mystiska varelser framstår som personifiering av de utsatta barnens rädslor, berättelser hjälper att besvärja det onda men representerar också längtan efter att få uppleva något utöver det vardagliga, att bryta ut och börja om igen. Det är inte utan anledning som Agneta Plejiel (2011) anser att Kjell Johansson i sina böcker har skildrat "hundra år av utsatthet”. Hon anspelar därmed på Gabriel García Márquez Hundra år av ensamhet, den roman som anses vara den magiska realismens främsta representant och på den roll som inriktningen har spelat för att lyfta upp den glömda historien.

\section{Berättelsen om folkhemmet}

Berättelsen om mönsterlandet och berättelsen om monsterlandet är, som Conny MITHANDER (2002, jfr WIKLUND 2006:11f) påpekar, de två centrala och varandra motsatta berättelserna $^{12}$ om den svenska välfärdsstaten. De förekommer sällan i sin renodlade form utan fungerar som symboliska samlingsbegrepp för en mängd berättelser med både utifrån- och inifrånperspektiv som florerar i politisk propaganda, samhällsdebatt och vetenskaplig diskurs.

Berättelsen om mönsterlandet syftar på den utopiska, framtidsoptimistiska, "ljusa" bilden av Sverige som föregångare på alla områden, den bästa platsen på jorden att leva

12 Begreppet "berättelse" syftar här på de narrativa konstruktionerna som används för att presentera olika möjliga tolkningar av ett historiskt skeende. Att uppfatta historien som en samling tolkningsmöjligheter ingår i en postmodernistisk syn på relationen mellan det förflutna, nutiden och framtiden. Bland forskarna som ansluter sig till denna uppfattnig kan man nämna Hayden White, Paul Ricoeur, Tomas Hylland Eriksen, Reinhart Kosselleck eller Jörg Rüssen (Jfr ŻMUDA-TRZEBIATOWSKA 2014). 
i och förebild för alla andra länder. Den associeras först och främst med den socialdemokratiska framgångsberättelsen om Sveriges utveckling från ett efterblivet bondesamhälle till ett välutvecklat industriland och samtidigt ett modernt, rationellt och jämlikt folkhem, där två typer av gemenskap, folkgemenskapen i en modern nationell stat och familjegemenskapen i ett tryggt hem, skulle skapa en helt ny kategori av medborgare. Berättelsen inbegriper också de utländska journalisternas lovord för den välfungerande svenska modellen.

Berättelsen om monsterlandet är mörk och dystopisk, präglad av avståndstagande eller fördömande syn på det stora socialdemokratiska samhällsprojektet som spårat ut, försatt landet i ekonomisk kollaps och lämnat de fördummade medborgarna i sticket. Denna föreställning är i en viss mån påverkad av de utländska kritikernas retorik. Den hade grott i oppositionens led och kom att dominera den politiska och samhälleliga debatten efter det borgerliga maktövertagandet 1991. I detta sammanhang är det också viktigt att påpeka att berättelsen om monsterlandet som syftar till att vederlägga berättelsen om mönsterlandet inte skulle kunna finnas utan den sistnämnda. På ett liknande sätt behövdes berättelsen om Fattigsverige som motbild när berättelsen om mönsterlandet växte fram på 1940-talet.

Undersöker man närvaron av de folkhemska berättelserna i Kjell Johanssons barndomsskildring får man konstatera att mönsterberättelsen, eller närmare bestämt den stora socialdemokratiska berättelsen används i romanen som en viktig referens. Huset vid Flon förefaller i första hand vara en berättelse om övergången från Fattigsverige till folkhemmet, vilket inte är konstigt med tanke på att romanens handling utspelar sig vid slutet av 1940- och under första delen av 1950-talet, då det gamla och det nya fortfarande existerar bredvid varandra, minnen om den gångna tiden är levande hos den äldre generationen och uppfyllning av politiska löften kan beskådas med egna ögon. Det gamlas symboler är smuts, dålig hygien, sjukdom och vidskepelse. För det nya står moderna bostäder, renlighet, hälsa och vetenskap och teknik (LINDERBORG 2004: 91).

I Huset vid Flon kan Fattigsverige identifieras i en rad vardagsdetaljer: det är halmen som fyllning till madrasserna, pumpen på gården istället för rinnande vatten, "pissknuten" och utedasset som får duga i avsaknad av toalett, utdragssoffan i köket och inneboende herrn Ivarsson, sparsam hushållning med maten samt några andra vanor med rötter i bondesamhället som att visa respekt för överheten eller hysa misstro mot det som avviker från allmänt rådande normer. Det det nya representeras bl. a. av spårvagnar som förbinder förorten med stadscentrum, telefonen som installeras i huset, mormorns löständer och asfaltering av Midsommarkransens gator.

Den sistnämnda händelsen har en speciellt stor symbolisk laddning eftersom berättelsen om övergången sammanfaller med berättelsen om arbetarklassen som folkhemsbyggare (som annars knappast exponeras i boken) och kan dessutom vara ett exempel på tematisering av arbete som ett karakteristiskt drag i arbetarromanen. Pojken iakttar bygg- och vägarbetarna med en blandning av skepsis och nyfikenhet. Han har påverkats av sin fars åsikter om att arbete behövs för att skaffa pengar men inte ger någon glädje och stolthet. När han lyssnar på arbetarnas rop tror han sig dock höra något annat, en särskild klang: 
"Arbetare ropade till varandra men de meddelade också oss andra att här fanns det folk som högg i och gjorde skäl för lönen. Det fanns självmedvetenhet i ropen som senare skulle bli ännu tydligare, i takt med den allt snabbare förvandlingen av det gamla Bonnsverige. Här är vi, vi som bryter mark, bygger hus och asfalterar de gamla grusvägarna. Kom igen!” (JOHANSSON 2003: 84).

Avslutningen på scenen förefaller också symbolisk: Eva och hans bror får sitta i knät på den ljushårige, visslande vältföraren som de beundrar, hålla i ratten och åka en runda. Pojken föreställer sig sin far som en av de hedervärda arbetshjältarna (JOHANSSON 2003: 85f).

Den som berättar om nöden, slitet och svårigheterna med att klara livhanken som hon upplevde i Fattigsverige är mormorn. "För henne stod den tiden som kontrast till hur bra de nu hade fått det och var ett bevis på att utvecklingen gick i sin rätta riktning”, förklarar berättaren (JOHANSSON 2003: 73). Som jag redan påpekat tidigare är mormorn den gestalt som är trogen anhängare av socialism och förkunnar sin politiska åskådning till övriga familjemedlemmar. Hennes framtidstro kan förefalla lite naiv men är orubblig och den profetia hon yttrar om den nya bättre världen som ska växa upp ur krigets aska framstår som ett citat ur socialdemokratens officiella propaganda: "I täten skulle Sverige gå, ty visserligen var Hjalmar Branting död sedan länge men Tage Erlander hade axlat hans mandel och produktionen skulle snart stiga till oanade höjder" (JOHANNSSON 2003: 74). Därmed räknas också mormorn in bland skapare och spridare av berättelsen om mönsterlandet.

Berättaren i romanen tillhör däremot generationen som uppfostras till goda medborgare i folkhemmet. Skolbadet skulle ge möjlighet att tvätta bort smutsen från kroppen (JOHANSSON 2003: 121ff), placering i fosterhem behövdes för att rengöra "tattarsjälen" (JOHANSSON 2003: 145ff; 155ff).

I det kända folkhemstalet från år 1928 målade Per Albin Hansson upp det framtida Sverige som ett tryggt och lyckligt medborgarhem ett klasslöst samhälle utan kelgrisar och styvbarn. Hans vision har ersatt de förvittrade stormaktsdrömmarna och den sociala sammanhållningen i bondesamhället som gick förlorad till följd av industrialisering och urbanisering av landet (jfr ŻMUDA-TRZEBIATOWSKA 2014). I Huset vid Flon tycks berättelsen om gemenskapen som utgör den viktigaste komponenten i den socialdemokratiska folkhemsberättelsen utebli eftersom karaktärernas utsatthet står i bjärt kontrast till Per Albins löften. Detta påminner om den tidigare diskuterade berättelsen om "den oskötsamme arbetaren” som är Kjell Johanssons sätt att vederlägga arbetarklassmyten. Med sin skildring av utsatthet och utanförskap ifrågasätter han folkhemmets viktigaste grundval - myten om gemenskapen. Gestalterna i boken, i synnerhet Anna och barnen önskar att få vara som alla andra, få leva sitt liv utan att bli utpekade som en smutsfläck i det perfekta samhället, de vill ha möjlighet att bevisa att de duger. Och de får de till sist efter att ha kämpat hårt, men priset som de betalar är högt.

Att Kjell Johansson har skrivit sin roman med facit i handen, dvs. haft kunskap om allt som hände mellan berättelsetiden och berättandetiden, dvs. mellan 1940-talet, 1950-talet och andra hälften av 1990-talet, är en omständighet som skapar ett dubbelperspektiv. 
I det avseendet påminner Huset vid Flon om andra svenska skildringar om barndomen i folkhemmet som har en retrospektiv karaktär och en vuxen berättare som tar sig friheten att kommentera de händelser som tidsmässigt motsvarar bokens handling men också med anmärkningar eller påannonseringar föregripa det som ska hända. ${ }^{13}$

I Johanssons reflexion kring den samhällsomvandling som Sverige har genomgått ser man en tydlig kritik av det oansvariga sättet att förvalta folkhemsprojektet, de genvägar som man gått och olika negativa följder av makthavarnas försummelser:

\begin{abstract}
"När människan i framtiden stannade upp och betraktade sin skapelse, vad såg de då? Jo, att fattigdomen avskaffats, att det i den nya byrån låg en bankbok där fordom motboken legat och att arbetarna hade svingat sig upp och bytt identitet, till kylskapsägare, snabbköpskunder, radiogrammofonspelare, televisionsinnehavare och arga skattebetalare. Klassamhället avskaffades på ett genialt sätt, man slutade tala om det, och ingen med undantag av mormor kom längre på tanken att hala fram Branting för att bevisa att socialismen var nära och att arbetarklassen nu var »stark och fruktad, politiskt fullmyndig, andligt frigjord, beredande sig att taga samhällets faktiska ledning i sina händer” (JOHANSSON 2003: 201f).
\end{abstract}

Med stor skepsis ser författaren på framgångspropagandan i USA:s anda, samt den nya konsumtionismens "slit-och-släng"-filosofi (JOHANSSON 2003: 202f). Dessa stundom mycket bittra kommentarer kan dock knappast kopplas till den borgerliga berättelsen om monsterlandet utan tycks grunda sig i den debatt om folkhemmets brister som pågått på vänstersidan av den politiska scenen.

Funderingar kring Huset vid Flon som en berättelse om folkhemmet leder till konstaterandet att Kjell Johanssons roman består av två berättelsenivåer. På den första återskapas släkthistorian och berättarens barndom. Den realistiska berättelsen om utsatthet som man drabbas av inom den egna klassen får en magisk inramning. På den andra nivån utvecklas en personlig hållen berättelse om folkhemmet som inbegriper delar av den socialdemokratiska berättelsen om mönsterlandet men också en stor dos kritik. I denna folkhemsskildring är det magiskrealistiska också närvarande. De olika världar som griper in i varandra är i Huset vid Flon inte bara den realistiska världen och fantasivärlden utan också den gamla och den nya verkligheten som karaktärerna balanserar mellan. Berättelser om förr och nu som skapas i romanen kan likställas med övergången mellan olika livsskeden som i flera kulturer är en magisk ritual. Ett annat intressant grepp som Johansson tillämpar är att jämföra den privata och den kollektiva - samhälleliga och nationella metamorfosen som upplevdes av respektive Lilly Klarin och Bondsverige:

\footnotetext{
"Under något decennium ska gamla Fattigsverige förvandlas till ett modernt välfärdssamhälle, det svenska undret bli ett faktum, moder Svea, en av de fattigaste av Europas alla fattiga kärringar ska rissla om på nolltid och bli modell, en förändring till och med större än den mirakulösa metamorfos Hon den tjocka kommer att genomgå...” (JOHANSSON 2003: 180).
}

13 Jag tänker här bl. a. på Underdog av Torbjörn Flygt (Jfr ŻMUDA-TRZEBIATOWSKA 2014). 


\section{Berättelsens makt}

Magnus NILSSON påpekar att den förnyelse som på senare år har observerats i den svenska arbetarlitteraturen kan gälla motiv och tendens men också innebär ett försök att använda sig av populärkulturens berättarformer. Han anser att "dessa förändringar av berättande inte främst handlar om kreativ förnyelse av den arbetarlitterära traditionen utan om en defensiv anpassning till en borgerlig kulturell hegemoni” (2004:185). Slutsatser som man drar efter att ha analyserat Kjell Johanssons roman tyder på något annat. Den magiskrealistiska konventionen som författaren valt för sin barndomsskildring i folkhemmet kan knappast betraktas som "defensiv anpassning" utan framstår som ett lyckat försök att förnya arbetarromanen genom att hitta en för läsaren attraktiv form. Det handlar dock inte om någon vacker förpackning som har estetiskt värde men saknar koppling till budskapet. Tvärtom. Den magiska realismen har i romanen två viktiga funktioner. Det blir ett sätt att föra fram de bortglömdas talan, sätta i fokus dem som en gång vägrades tillgång till gemenskapen. Samtidigt visar sig den magiskrealistika konventionen vara till stor hjälp vid försöken att återberätta folkhemmet som ett möte mellan olika världar, en skådeplats för uppfyllda och spruckna drömmar och svenskarnas kollektiva arv. Dessa två berättelser flyter ihop och blir till en stark röst i debatten om folkhemmet. "Berättelser kan man ha till mycket", som Kjell Johansson själv uttryckt det i sin bok (2003:90).

\section{Litteratur}

AHLMO-NILSSON, Birgitta (1979): Inledning till IDEM: Inte bara kampsång. Fjorton analyser av arbetarlitteratur. Lund, s. 8-23.

FARIS, Wendy B. (1995): Scheherazade's Children: Magical Realism and Postmodern Fiction. I: ZAMORA, Lois Parkinson, Wendy B., FARIS (red.): Magical Realism. Theory, History, Community. Durham \& London, 163-189.

FURULAND, Lars (1999). Folkrörelser och arbetardikt ca 1880-1920. I: LÖNNROTH Lars, Sven DELBLANC, red.: Den svenska litteraturen. Genombrottstiden 1830-1920. Stockholm, s. 521-546.

FURULAND, Lars, SVEDJEDAL, Johan (2006): Svensk arbetarlitteratur, Stockholm.

JOHANSSON, Kjell (2003): Huset vid Flon (pocketuppl.). Stockholm.

LINDERBORG, Åsa (2004): Historical romanticism and development optimism: on the historical perception of social democracy. I: ALMQVIST, Kurt, Kay GLANS (red.) The Swedish Success Story? (eng. övers. av Paul Fischer).Stockholm, s. 81-95.

LUTHERSSON, Peter (1999): Från litteraturkris till litteraturkris - nedslag i textvärlden. I: LÖNNROTH, Lars et al. (red.): Den svenska litteraturen. Från modernismen till massmedial marknad 1920-1995. Stockholm.

MASDEU, Paola (2007): Övernaturliga vardagar. En studie av det övernaturliga i svensk litteratur som medel för social kritik. Magisteruppsats. Södertörns högskola. http://sh.diva-portal.org/ smash/get/diva2:15480/FULLTEXT01.pdf (20. 5. 2016).

MITHANDER, Conny (2002): Från Mönsterland till Monsterland. Folkhemska berättelser. I: 
BERGVALL, Åke et al. (red.). Berättelser i förvandling - berättande i ett intermedialt och tvärvetenskapligt perspektiv (Karlstad University Studies 12). Karlstad, s. 53-85.

NILSSON, Magnus (2004): Arvet från 30-talet i nyare svensk arbetarlitteratur. I: Gemzø Anker et al. (red.) Fortællingen i Norden efter 1960. Den 24 IASS-studiekonference 2002. Alborg, s. $185-191$.

NILSSON, Magnus (2006a): Arbetarlitteratur. Lund: Studentlitteratur.

NILSSON, Magnus (2006b): Arbetarlitteratur, identitet, ideologi. Tidskrift för litteraturvetenskap 3-4, s. 154-177.

PLEIJEL, Agneta (2011): Så skildrar Kjell Johansson hundra år av utsatthet. Dagens Nyheter 20.09. http:/ / www.dn.se/kultur-noje/kulturdebatt/sa-skildrar-kjell-johansson-hundra-ar-av-utsatthet/ (20.5 2016).

WIKLUND, Martin (2006): I det modernas landskap. Historisk orientering och kritiska berättelser om det moderna Sverige mellan 1960 och 1990. Eslöv.

ŻMUDA-TRZEBIATOWSKA, Magdalena (2014): Myten och dess arvtagare. Historiska och skönlitterära berättelser om folkhemmet, Folia Scandinavica Posnaniensia vol. 16, s. 92-113.

ÖHRSTRÖM, Liljan (2003): Jag skulle ha ett annat liv (intervju med Kjell Johansson). Dagens Nyheter 31.08. http:/ / www.dn.se/nyheter/jag-skulle-ha-ett-annat-liv (10. 7. 2010).

Magdalena Żmuda-Trzebiatowska, PhD / magdazt@amu.edu.pl

Uniwersytet im. Adama Mickiewicza, Katedra Skandynawistyki, Collegium Novum al. Niepodległosci 4, 61-874 Poznan, Poland 